\title{
PEDAGOGICAL TECHNOLOGY DEVELOPMENT OF METHODICAL CULTURE OF FUTURE TEACHERS
}

\section{Knyazheva I. A.}

\section{INTRODUCTION}

Globalization processes taking place in the world require constant analysis and permanent innovative changes in all spheres of social life, including higher education. Future specialists - a new generation of "problem solvers" - are required to be prepared for constant personal changes and to adapt to constantly changing social conditions and productive activities in the harsh conditions of competition in the labor market. The current stage of high pedagogical education development, its integration into the European educational community is characterized by topical necessity in student-centered learning, replacing ineffective verbal ways of knowledge transfer, creation and implementation of pedagogical technologies providing guaranteed learning results of high quality. Nowadays, the idea of changing the tasks of the education system find more and more supporters.

Educational institutions should not only and not so much distribute educational information, as to be institutions designed to implement the general cultural changes, teach not only to consume, but also to produce, create, develop new skills and opportunities for students. Solution to the aforementioned problems largely depends on the development of methodical culture of future teachers and transferring this process onto technological footing.

Nowadays, there is a major demand for efficient professional training of pedagogical specialists all over the world. This problem was particularly intensified by the outbreak of the Covid-19 pandemic, which requires educators to create, develop and use new effective innovative methods and technologies of learning.

The purpose of the study is to present to the international pedagogical community the peculiarities of the technology of methodical culture

1 Mc Arthur J.W., Sachs J. Needed: A new generation of problem solvers. Chronicle of Higher Education. 2009. № 55 (40). P. 1-4. URL: https://www.chronicle.com/article/needed-a-new-generation-of-problem-solvers. 
formation of future teachers, opportunities and experience of its use in the educational process of higher education institutions.

\section{Analysis of publications and research methods}

The necessity to revise the "knowledge-based approach to education" made scientists and practitioners both in Ukraine and in other countries review the fundamental approaches to building education. In this regard, more and more attention, especially in the humanities, is being paid to the practical, methodological component of professional education.

The need to indicate the professional affiliation of a technology caused the appearance a new term - "pedagogical technology". At the same time, it should be noted that the fact that this term combines two rather capacious concepts - "pedagogy" and "technology", has led to a lack of unity of views on its interpretation. In addition, in educational and scientific practices there are the terms "educational technology", "pedagogical technology", "learning technology". They are often used as synonyms, citing a reference to the English "an educational". Their comparison as categories "pedagogy", "education", "training" is also quite common, emphasizing that the concept of "pedagogical technology" covers the processes of education, training and upbringing. In the disquisition here and then we will use the term "pedagogical technology", as we consider it the most appropriate in terms of purpose, content and targets.

According to UNESCO, pedagogical technology is interpreted as a systematic method of planning, creating, applying and evaluating the entire process of teaching and learning through the accounting of human and technical resources and their interaction to achieve a more effective form of education ${ }^{2}$.

V.M. Monakhov made a very successful description of the peculiarities of pedagogical technology. He defines it as a well-thoughtout model of joint pedagogical activity in the design, organization and conduct of the educational process with the provision of comfortable conditions for teachers and students ${ }^{3}$.

V. O. Slastyonin defines pedagogical technology as a natural pedagogical activity that implements a scientifically sound project of the

${ }^{2}$ Пєхота О.М. Освітні технології : навчально-методичний посібник. Київ : A.C.K., 2001. 256 c.

${ }^{3}$ Монахов В.М. Технологические основы проектирования и конструирования учебного процесса. Волгоград : Перемена, 1995. С. 25. 
didactic process and has the highest degree of efficiency, reliability, more guaranteed result than when using traditional teaching methods ${ }^{4}$. It is this definition that we accept as working, because in it pedagogical technology is presented as a means of guaranteed achievement of learning goals; the project of a certain controlled pedagogical system, which contains the tools necessary for its implementation and the algorithm of its application.

The principles of pedagogical techniques are covered in the works of M. V. Klarin ${ }^{5}$, D. Littlewood ${ }^{6}$, C. A Rogers ${ }^{7}$ etc. The studies provide data on the impact of personality technologies focused on the quality of training and academic productivity of university students ${ }^{8} ;{ }^{9}$. The data obtained indicate the need to increase the guaranteed positive result of vocational training. Such results, as evidenced by scientific research data $^{10}$, can be obtained as a result of the use of pedagogical technologies. At the same time, among the available various pedagogical technologies, there is no technology for the development of the methodological culture of future teachers. This is what determines the novelty of the materials proposed by the author in the study.

Analysis of the conducted research ${ }^{11}$ allows to determine the development technology of methodical culture of future teachers of pedagogical disciplines as theoretically justified systematically structured process of setting and guaranteed effective implementation of

4 Сластенин В.А., Исаев И.Ф., Шиянов Е.Н. Педагогика. Москва : Издательский центр «Академия», 2002. $576 \mathrm{c}$.

5 Кларин М.В. Педагогическая технология в учебном процессе. Знание «Педагогика и психология». 1989. № 6. С. 278.

${ }^{6}$ Littlewood D. Self access: Why do we want it and what can it do? Autonomy and independence in language learning / Ed. by P. Benson and P. Voller / London and New York : Longman, 1997.

Rogers C.A. Client-centered/Person-centered Approach to Therapy. Psychotherapist's Casebook. Jossey-Bass. 1986. P. 197-208.

8 Чошанов М.А. Гибкая технология проблемно-модульного обучения : методическое пособие. Москва : Народное образование, 1996. 160 с.

${ }^{9}$ Marín M., Infante E., Troyano Y. Personality and academic productivity in the university student. Social Behavior and Personality. 2001. № 3 (29). P. 299-306. URL: https://www.sbp-journal.com/index.php/sbp/article/view/1082.

${ }^{10}$ Селевко Г.К. Энциклопедия образовательных технологий : в 2 т. Т. 1. Москва : Народное образование, 2005. 525 с.

11 Княжева I.A. Теоретико-методологічні засади розвитку методичної культури майбутніх викладачів педагогічних дисциплін в умовах магістратури : монографія. Одеса : ФОП Бондаренко М.О., 2014. 328 с. 
planned results (increasing of methodical culture level) in certain algorithm, provided by tools, methods and forms of education, assures prompt feedback based on the diagnostic results according to methodical culture structure.

This definition comprises the main essential characteristics of pedagogical technology, namely a:

- clearly defined aim;

- guaranteed achievement through the use of reasonably tailored means, methods and forms of education; stages;

- clear sequence (algorithm) of targeted pedagogical activities

- tools for providing the development process managing ability;

- presence of feedback.

Analysis of scientific publications ${ }^{12}$ and results of own research proved variability of pedagogical technologies structure and allowed to determine the components of the development technology of methodical culture of future teachers, among them are:

- goal setting (development and description of the goals and objectives that allow consistent planning and implementation of pedagogical process within a given pedagogical technology);

- conceptual framework; content (content, volume, character and structure of educational materials, programs);

- procedure part (specifics of the process: forms, methods and techniques of training, teaching, diagnosis, and correction).

This is the complete structure for the development and description of the technology proposed in this study.

To solve the tasks of the research, the following set of methods was used: theoretical methods (theoretical analysis of scientific and methodical literature, regulations in the field of education, educational standards, typical curricula and programs, as well as a variety of electronic documents; the study of advanced educational experience; systematization of theoretical data). The use of theoretical methods made it possible to prove the actuality, to create a theoretical foundation and to develop conceptual provisions of the technology for the development of methodological culture of future teachers, to generalize and systematize the data obtained.

12 Дичківська І.М. Інноваційні педагогічні технології : навчальний посібник. Київ : Академвидав, 2004. 351 с. 
Empirical methods were used (questioning and survey of teachers and students of the pedagogical university), as well as methods of mathematical statistics using computer technologies for processing the data obtained. These methods were used to identify and analyze the existing opinions and views of the respondents on the relevance of the problem of forming the methodological culture of future teachers.

These methods belong to the methods of pedagogical diagnostics. We understand pedagogical diagnostics as a system of methods and means of measuring the quality of professional training of students of higher education institutions, which provides information on the presence of gaps in the educational process, promotes awareness and search for optimal ways to overcome them ${ }^{13}$.

At the beginning of the work, an individual single oral survey was carried out among teachers of pedagogical disciplines, suggesting an expeditionary method of conducting (the registrar himself filled out the form of answers to questions from the respondent's words). To conduct a survey, the authors of the study developed a questionnaire, and to analyze the data obtained, a group of experts was formed from among doctors of pedagogical sciences and heads of pedagogical departments of the South Ukrainian National Pedagogical University named after K.D. Ushinsky, as well as employers - school directors. 19 respondents took part in the survey (the sample was made up of teachers with a Ph.D. degree in pedagogical sciences who teach pedagogical disciplines at Ushinsky University (Odessa, Ukraine) and who have expressed a desire to participate in the proposed type of work). The thematic axes of the survey were a series of questions that related to the views of teachers on the need to form a methodological culture in future teachers, the techniques and / or technologies they know to help solve this problem, questions about the presence or absence of motivation to master them and aimed at clarifying the obstacles known to respondents. on the way to its implementation. Also, the authors of the study developed a questionnaire for students of the pedagogical university. The questionnaire assumed a correspondent (written) way of filling out and contained a series of open, detailed questions.

The thematic axes of the proposed questionnaire were questions about the essence of methodological culture, students' motivation and interest

13 Сопівник І.В., Дука Т.М., Підлипняк І.Ю. Діагностика професійної підготовленості студентів до педагогічної діяльності. Наука $і$ освіта. 2017. № 12. C. 59-65. DOI: https://doi.org/10.24195/2414-4665-2017-12-8. 
in methodological activity, difficulties in its implementation both during training (quasi-methodical activity) and during the period of pedagogical practice (methodological activity itself), the needs and readiness of respondents to the formation of a methodological culture during training at a pedagogical university. Let's give an example of evaluating the results obtained on the first question of the questionnaire. For this, the following quantitative assessment scale was developed: less than 4 points - a low level of formation of the ideas of future teachers about the essence of methodological culture; from 4 to 8 points - satisfactory level; more than 8 points is a sufficient level. 59 students of pedagogical specialties of 2-3 courses (Ushinsky University, Odessa, Ukraine) were admitted to the survey. The representativeness of the sample was proved using the methods of mathematical statistics (V.I. Paniotto's method using the calculation of the boundary error according to the theorem of P.L. Chebishev).

The results of the survey at the beginning of the study showed that the majority of teachers $(89,5 \%)$ understand the need and importance of the formation of future teachers of methodological culture as an important indicator of readiness for professional activity.

They assessed as insufficient (79\%) to solve this problem known to them methods and technologies of work in higher education and awareness of the need to create new methods and technologies for the formation of methodological culture of future teachers.

A survey of students showed that the vast majority of future teachers $(96,6 \%)$ are aware of the need to form a methodological culture for the successful performance of professional duties of a modern teacher.

Students (85\%) noted the difficulties associated with the need to create various methodological products (writing lesson plans, extracurricular activities, creating test tasks and tasks to test student achievement and others).

Such results of the questionnaire led to the creation of technology for the formation of future teachers of methodological culture in the process of learning in higher education.

\section{Characteristic of pedagogical technology development of methodical culture of future teachers}

Since any structural and projecting activity usually begins with setting goals of this activity, let us consider goal-setting as a first structural component of technology of methodical culture of future 
teachers. Goal setting we should understand ${ }^{14}$, as forming the subject basics of necessary activities, motives, goals, objectives, as the process of generating new ideas and setting goals.

The result of goal-setting is construction of hierarchically ordered list of goals, i.e. creation of a "tree" of goals, each "layer" of which defines its scope, status and area of implementation. Among them strategic (define overall strategy and therefore are relatively general and stable), tactical (as specification of strategic goals, they describe the way to achieve it, acting as its components dedicated to a particular stage of its solution is more specific and dynamic) operational (constructed in accordance with current teaching situations that arise in education, they are more volatile and dynamic) are usually distinguished.

Strategic aim of the development technology of methodical culture of future teachers is improving of methodical culture of of future teachers. The next "layer" of goals is formed by subordinate to strategic goal tactical targets, including of future teachers appropriation of knowledge required for description and explanation of the problematic methodological challenges, self-improving in the culture appropriate to teaching activities; formation of general and specific teaching skills, providing culture appropriate professional activity of future teachers, the ability to control actions of its members that determine its ability to develop and implement cultural practices in the content of pedagogical activities; formation and development of the ability to analyze, introspect and evaluate the effectiveness of professional activities and teaching products, match the accumulated knowledge and cultural experience of teaching; awareness of the need for methodological activity, professional development needs for self-realization, formation and development of a positive attitude towards future profession.

Special role in the specification of goals is their transformation into a system of tasks, which are to facilitate of future teachers in professional language learning, understanding basic methodological and pedagogical knowledge about the main activities and functions of the teacher; the nature, purpose, objectives function, direction, content and form of implementation of methodological activities of teachers in modern university, the essence of its methodical culture, etc.; development of the ability to perform the selection of teaching methods for teaching; implement various teaching positions and roles of the teacher

14 Петровский В.А. Личность в психологии: парадигма субъектности. Ростов-на-Дону : Феникс 1996. 512 с. 
(as moderator facilitator, methodologist, tutor, coach, playing master); master technique selection and use of learning methods in teaching; methods of planning educational process teaching in high educational institutions; master teacher algorithm of preparation to various kinds; master ways of creation and variants of presentation of teacher methodical activity products; ability to adequately use the previous and current experience of pedagogical activity of university professors in accordance with the specific situation, etc.

Description of the conceptual foundations of the development technology of methodical culture of future teachers, presenting this educational process as manageable, the main purpose of which is to create conditions for the development and self-development of future teachers, aims to disclose the external conditions for its implementation. That is why the key points are presented in the form of pedagogical conditions which were justified by the author in a previous publication ${ }^{15}$.

The use of the term "pedagogical conditions" is associated with the need to solve various purely pedagogical problems and in a generalized interpretation can be defined as a set of measures aimed at improving the effectiveness of pedagogical activities ${ }^{16}$; circumstances that determine the formation and development of pedagogical phenomena, processes, systems ${ }^{17}$; factors that affect the process of achieving the goal and are the result of selection, design and application of elements of content, forms, tools, technologies, methods and techniques of teaching and education that contribute to the effective solution of tasks ${ }^{18}$.

Pedagogical conditions are defined as external and internal circumstances, factors, a set of measures that contribute to the successful course of a particular phenomenon, the implementation of which aims to ensure successful organizational and pedagogical, psychological and

15 Trust T. Preparing future teachers to redefine learning with technology. Journal of Digital Learning in Teacher Education. 2017. № 33 (2). P. 44-45. doi.org/10.1080/21532974.2017.1281654.

16 Никитина Е.Ю. Теория и практика подготовки будущего учителя к управлению дифференциацией образования : дис. ... докт. пед. наук : 13.00.08. Челябинск, 2001. 427 с.

17 Кустовська О.В. Методологія системного підходу та наукових досліджень : Курс лекцій. Тернопіль : Економічна думка, 2005. 124 с.

18 Алексюк А.М., Аюрзанайн А.А., Підкасистий П.І. та ін. Організація самостійної роботи студентів в умовах інтенсифікації навчання : навчальний посібник. Київ : ІСДО, 1993. 336 с. 
pedagogical, didactic support of the processes of formation and development of methodological culture.

Thus, the conceptual framework of developed technology is the statements that the effective development of methodical culture of future teachers that currently are:

- coverage of the content of professional training of future teachers methodical nature of culture as a social and cultural phenomenon and personal innovation, awareness of the significance of which will result in the context of educational activities;

- acquisition of personal experience of educational activities implementation needed for analysis, selection and creation of teaching products;

- providing educational autonomy of future teachers in terms of their master's training.

\section{Content component of the development technology of methodical culture of future teachers}

Content component of the development technology of methodical culture of future teachers is built using the invariant and variant approaches that allow, on the one hand, to ensure the internal integrity of the content of the developed technology associated with traditional direct transfer of pedagogical and humanistic values (herewith the necessary process of society reproduction is provided), and on the other hand, to adapt it to its concrete changing historical reality and adjust it to take into account the personal needs of each graduate student.

Invariant provides a platform for educational standard as a system of parameters that act as standards of education policy, reflecting the ideal of public education and take into account the real possibilities of the individual and society in achieving this ideal. Invariant of the course is a relatively stable "core" of the discipline, required minimum, which plays an important role and determine the effect of continuous education. The richer and more saturated is the core, the longer and more promising path of education is. The invariant should include general ideas, issues, rather than specific facts. It is largely determined by such relations of subjects and objects of the pedagogical process that tend to repeat. The main mastering subject are values, criteria and mechanisms of teacher creative work aimed at enriching the spiritual world of the student, development of his cognitive powers and abilities. Invariant component provides organic "building-into" all required content and form of work in the process learning by means of which pedagogical activities represent both 
a permanently deployed process and fixed at every moment of the process outcome that is already formed, but not "frozen".

Variable component acts as a condition for individual development of future teachers and lecturers, is determined by the individual demands and characteristics of the subjects of the educational process, features of lecturer's profession and allows efficient solving the problem of balance in training, development and self-development, to develop an individual program of personal and professional formation of future teachers.

The combination of invariant and variant approaches to content component of the development technology of methodical culture of future teachers is considered to be optimal, as they allow to clearly formulate the goals and objectives of each discipline, specify and agree on the content of the learning process, prevent unproductive repetition of certain topics, contribute to the preparation of new teachers that can effectively and creatively work in new, rapidly changing social conditions.

The content technology component is represented by the program of regulatory discipline "Methodology of teaching at high educational institutions", which includes meaningful units of material (theories, laws, problems, ideas, concepts, and facts presented in a particular structure). It is built in a modular fashion, according to which the content is divided into functional units - modules, each of which has a certain content structure, system of learning elements and is a complete cycle of training activities. Design of its content is made with the following requirements:

- determination to social needs, requirements of modern pedagogical education;

- reflection in the content of the current level of science development;

- compliance with the goals and objectives of technology;

- diagnostic orientation;

- professional orientation;

- informative part;

- feasibility;

- structural order;

- interdisciplinary connections.

The discipline "Methodology of teaching at high educational institutions" is the part of training experts at educational qualification level "Master". Its content extends the theoretical and practical base of knowledge and skills related to vocational activity of high school teacher; highlights legislative and normative acts regulating activities of 
high educational institutions in general and the work of teachers in particular, determine the prospects for their further development.

Developed discipline program includes four content modules:

- "Content and regulatory framework of discipline teaching of pedagogical in high educational establishment",

- "Organization of educational process in pedagogical high educational establishment",

- "Methods of designing and conducting various types of lessons",

- "Formation and development of methodical culture of future teachers".

Let us consider in more detail the contents of the aforementioned modules. So the first module involves the study of three topics: "Place of the discipline "Methodology of teaching at high educational institutions" in the structure of professional training of the lecturer in high educational establishment", "Legislation on the organization of educational process in pedagogical higheducational establishment", "Cycle of pedagogical disciplines and their training and methodological facilities".

Second content module includes five topics, namely:

- "Forms of organizing teaching and learning activities of students in the process of pedagogical disciplines learning",

- "Methodology of organizing independent work of students in the process of pedagogical disciplines learning",

- "Methodology of content design and management pedagogical practice of students",

- "Methods and means of teaching pedagogical disciplines",

- "Innovative approaches to teaching at high educational institutions".

Third content module includes four topics, which promote learning of methods of designing and conducting lectures, seminars, practical and laboratory lessons of pedagogical disciplines, methodology of designing and conducting monitoring of learning achievements of students of pedagogical disciplines that are primarily focused on the formation of action-organizational and reflective-evaluative components of methodical culture of future teachers.

Fourth content module "Formation and development of methodical culture of future teachers" includes working on the following topics:

- "The requirements for preparing future teachers for pedagogical high educational institutions",

- "Methodical culture in social and personal dimensions", 
- "Methodological component of professional activities of teacher as a source of its methodical culture".

The introduction of the mentioned topics, each of which is crosscutting across all forms of classes, independent and individual work of future teachers reflected in the content of pedagogical practice required selection and designing appropriate to the content active methods of its mastering and meant development of appropriate teaching tools: learning topics programs, methodological recommendations for their mastering, tutorials, software, tasks for independent work of students, educational programs of pedagogical practice in high educational institutions.

Through content component of development technology of methodical culture the first pedagogical discipline is implemented, namely covering in the content of professional training of future teachers methodical nature of culture as a social and cultural phenomenon and personal innovation, awareness of the significance of which will result in the context of educational activities.

Procedural component of component of the development technology of methodical culture of future teachers is a set of procedures aimed at implementation of gradual operational realization of goals and objectives of technology, deployment of its content using modern forms, tools, methods and techniques of pedagogical process.

Implementation of appointed component included regulatory fixed phases, sequence of which is logic of building of procedural component of the developed technology and meets the essential nature of the methodical culture. Three phases are determined: phase of culture acquiring, phase of culture reproduction and phase of culture creation.

The phase of culture acquiring included appropriation of "sustainable" culture of society, exploring and finding information that has cultural and historical invariants of pedagogical activities of teachers. It is worth mentioning that the "sustainable" culture acquiring does not mean memorizing various facts, concepts, ideas, and algorithms of activity. Important here was their analysis, critical overview, reflection, making own conclusions. The phase of culture reproduction as methodological and pedagogical activity is made by certain algorithm, creation of a methodological product after the best model. The phase of culture creation included creation of its own methodological product (such as having novelty in a subjective and objective way).

Selection of technological procedures that defined instrumental equipment of technology is done by considering classical and specific criteria, such as: 
- compliance of principles and methods with teaching techniques, learning goals and objectives, the content of learning materials, possibilities, students potential (initial state);

- compliance with the circumstances and the time allotted for learning, teachers opportunities;

- criteria for appropriateness and compatibility.

Phase I. Methodological tools (forms and methods): problematic lectures, lecture - imaging, electronic lectures, lecture-presentations, lectures-dialogues, workshops (traditional, in-depth study, special seminars, interdisciplinary special seminars), independent work, pedagogical practice; pedagogical situations solving, portfolio method, project method, a method of logical-conceptual models, brainstorming, discussion method, discussion, heuristic conversation, mind map, emotional stimulation learning method, etc.

Phase II. Methodological tools (forms and methods): workshops, pedagogical practice, independent work, business and role-playing games, pedagogical situations solving, modelling, case method, mind map, educational consultation, workshops, virtual methodical study, a method of logical- conceptual models, etc.

Phase III. Methodological tools (forms and methods): workshops, self-education, pedagogical practice, virtual methodical study, and workshops; project method, portfolio method, participatory method, a method of logical-conceptual models, simulation method, etc.

Each phase obligatory included analytical block with the function of feedback. It meant reflection, teacher evaluation of his actions and comparison with the results of future teachers' activities, joint discussion of current data resultsquality monitoring, of future teachers' selfevaluation of their own achievements and the ability to correct.

Pedagogical technology is implemented in accordance with certain pedagogical conditions and principles in the process and on the material of the normative discipline "Methods of teaching pedagogical disciplines in higher education" and pedagogical practice in higher education through the deploymen of phases. The phase of cultural development involved the appropriation of "sustainable" culture of society, the accumulation of cultural pedagogical experience through acquaintance with it and finding information that contains cultural and historical invariants of pedagogical activities of teachers. The phase of cultural reproduction involved the implementation of existing cultural practices mastered by future teachers, provided for the transformation of pedagogical reality, the implementation of culturally appropriate 
pedagogical activities, selected by criterion selection algorithm of action, creating a methodological product on the model recognized as the best.The phase of cultural creation involved going beyond the typical, standard algorithms of activity, finding personal cultural meanings in them as the embodiment of subjectivity, required modeling of own options for solving various pedagogical problems, creating a subjectively and objectively new methodological product. It contained the appropriate technological procedures that determined its tooling.

Conducted in five universities of Ukraine (Odessa, Nikolaev, Uman, Mukachevo, Kherson) and confirmed by the relevant documents recommended by the Ministry of Education and Science of Ukraine (acts of implementation), the approbation of the technology developed by the authors of the study made it possible to speak of its effectiveness as a practical tool for the formation of methodological culture in future teachers.

\section{CONCLUSIONS}

Thus, the components of pedagogical technology for the development of methodological culture of future teachers are: goalsetting, conceptualbasis, content and procedural parts.

The goal settingwas to develop and describe strategic (raising the level of methodological culture of future teachers), tactical and operational goals, which allowed for planning and consistent implementation of the educational process within a given pedagogical technology.

The conceptual basis of pedagogical technology for the development of methodological culture of future teachers are pedagogical conditions.

The semantic component of pedagogical technology is formed due to a combination of invariant and variable approaches.

The procedural component of the pedagogical technology of development of methodical culture of future teachers was realized according to normatively fixed phases (cultural development, cultural reproduction and cultural creativity).

Passage of these phases forms logic of construction and corresponds to the essential nature of development of methodical culture, makes set of the procedures directed on realization of purposeful, step-by-step operational realization of the purposes and tasks of pedagogical technology, development of its maintenance by means of modern forms, means, methods and receptionsof organizing the educational process.

Thus, the essence of the development technology of methodical culture of future teachers is the availability of well-defined objectives, 
security of its achievement through the use of reasonably tailored to the conceptual basis of training forms and methods; clear sequence of phases, targeted pedagogical actions, available tools that provide feedback and manageability of the process.

Given the difficulties faced by university professors in preparing future teachers for methodological activities, we shared experiences and proposed a technology for forming methodological culture, the use of which in the educational process of the pedagogical university improves students' learning outcomes and their readiness to effectively fulfill their future professional duties. We hope that our technology of forming the methodological culture of future teachers at the university, which has been tested and used in five higher education institutions of Ukraine, will be useful for international education.

Prospects for further research are in the broad generalization of the results and introducing the development technology of methodical culture of future teachers. The authors believe that the experience of training masters in the State Institution "South Ukrainian National Pedagogical University named after K. D. Ushynsky" will also be useful for institutions of higher education in other countries. At the same time, we agree with Cemaloğlu ${ }^{19}$ and $\mathrm{Kamer}^{20}$, which, based on an analysis of the experience of Turkish education, argue that the specificity and traditions of each individual country should be taken into consideration.

\section{SUMMARY}

Nowadays, there is a major demand for efficient professional training of pedagogical specialists all over the world. This problem was particularly intensified by the outbreak of the Covid-19 pandemic, which requires educators to create, develop and use new effective innovative methods and technologies of learning. That is why the formation of the methodological culture of future teachers is an urgent task for pedagogical universities. The importance of this problem was confirmed by the survey and questionnaires conducted by the authors among teachers of the Pedagogical University and students. The difficulties they had in mastering modern educational technologies, writing class notes, test assignments and other teaching

${ }^{19}$ Cemaloğlu N. Osmanlı Devleti'nde Yapılan Tanzimat Reformlarının Eğitim Sistemine Etkileri, Uygulamaları ve Sonuçları (1839-1876). Manas Sosyal Bilimler Dergisi 7. 2005. № 14. P. 153-65.

${ }^{20}$ Kamer S.T. Evaluation of Public Education and Teacher Training on the Basis of 1869 Regulation in the Ottoman Era. Journal of History Culture and Art Research. 2020. № 9 (2). P. 15-24. DOI:10.7596/taksad.v9i2.2221. 
products were identified. The purpose of the publication is to familiarize the international pedagogical community with the peculiarities of the technology of forming the methodological culture of future teachers, the possibilities and experience of its use in the educational process of higher educational institutions. The study shows the main characteristics of pedagogical technology: a specific goal; guaranteed achievement of results; clear sequence of actions; the use of means and methods corresponding to the set of strategic and tactical goals; availability of feedback; monitoring of results. The pedagogical conditions are revealed, the implementation of which contributes to the formation of the methodological culture of future teachers. The approbation carried out at five universities of Ukraine (Odessa, Nikolaev, Uman, Mukachevo, Kherson) testifies to the expediency of using the pedagogical technology developed by the authors.

\section{References}

1. Mc Arthur J. W., Sachs J. Needed: A new generation of problem solvers. Chronicle of Higher Education. 2009. № 55 (40). P. 1-4. URL: https://www.chronicle.com/article/needed-a-new-generation-ofproblem-solvers.

2. Пєхота О.М. Освітні технології : навчально-методичний посібник. Київ : А.С.К., 2001. 256 с.

3. Монахов В.М. Технологические основы проектирования и конструирования учебного процесса. Волгоград : Перемена, 1995. $152 \mathrm{c.}$

4. Сластенин В.А., Исаев И.Ф., Шиянов Е.Н. Педагогика. Москва : Издательский центр «Академия», 2002. 576 с.

5. Кларин М.В. Педагогическая технология в учебном процессе. Знание «Педагогика и психология». 1989. № 6. С. 278.

6. Littlewood D. Self access: Why do we want it and what can it do? Autonomy and independence in language learning / Ed. by P. Benson and P. Voller. London and New York : Longman, 1997.

7. Rogers C.A. Client-centered/Person-centered Approach to Therapy. Psychotherapist's Casebook. Jossey-Bass. 1986. P. 197-208.

8. Чошанов М.А. Гибкая технология проблемно-модульного обучения : методическое пособие. Москва : Народное образование, 1996. $160 \mathrm{c}$.

9. Marín M., Infante E., Troyano Y. Personality and academic productivity in the university student. Social Behavior and Personality. 2001. № 3 (29). P. 299-306. URL: https://www.sbp-journal.com/ index.php/sbp/article/view/1082. 
10.Селевко Г.К. Энциклопедия образовательных технологий : в 2 т. Т. 1. Москва : Народное образование, 2005. 525 с.

11.Княжева I.A. Теоретико-методологічні засади розвитку методичної культури майбутніх викладачів педагогічних дисциплін в умовах магістратури : монографія. Одеса : ФОП Бондаренко М.О., 2014. $328 \mathrm{c}$.

12.Дичківська I.M. Інноваційні педагогічні технології : навчальний посібник. Київ : Академвидав, 2004. 351 с.

13. Сопівник I.B., Дука Т.М., Підлипняк I.Ю. Діагностика професійної підготовленості студентів до педагогічної діяльності. Наука $i$ освіта. 2017. № 12. С. 59-65. DOI: https://doi.org/10.24195/2414-4665-2017-12-8.

14.Петровский В.А. Личность в психологии: парадигма субъектности. Ростов-на-Дону : Феникс 1996. 512 с.

15. Trust T. Preparing future teachers to redefine learning with technology. Journal of Digital Learning in Teacher Education. 2017. № 33 (2). P. 44-45. doi.org/10.1080/21532974.2017.1281654

16.Никитина Е. Ю. Теория и практика подготовки будущего учителя к управлению дифференциацией образования : дис. ... докт. пед. наук : 13.00.08. Челябинск, 2001. 427 с.

17. Кустовська О.В. Методологія системного підходу та наукових досліджень : Курс лекцій. Тернопіль : Економічна думка, 2005. 124 с.

18. Алексюк А.М., Аюрзанайн А.А., Підкасистий П.І. та ін. Організація самостійної роботи студентів в умовах інтенсифікації навчання : навчальний посібник. Київ : ІСДО, 1993. 336 с.

19. Cemaloğlu N. Osmanlı Devleti'nde Yapılan Tanzimat Reformlarının Eğitim Sistemine Etkileri, Uygulamaları ve Sonuçları (1839-1876). Manas Sosyal Bilimler Dergisi 7. 2005. № 14. P. 153-65.

20. Kamer S. T. Evaluation of Public Education and Teacher Training on the Basis of 1869 Regulation in the Ottoman Era. Journal of History Culture and Art Research. 2020. № 9 (2). P. 15-24. DOI:10.7596/taksad.v9i2.2221

\section{Information about the author: Knyazheva I. A.,}

Doctor of Pedagogical Sciences, Professor, Head of the Department of Pedagogy South Ukrainian National Pedagogical University named after K. D. Ushynsky 26, Staroportofrankivska str., Odesa, 65020, Ukraine 